\title{
ОБРЯДОВІ ТАНЦІ-ІГРИ - МАЛОДОСЛІДЖЕНІ КОМПОНЕНТИ ТРАДИЦІЙНОГО ВЕСІЛЛЯ УКРАЇНЦІВ
}

\author{
Курочкін Олександр Володимирович, \\ доктор історичних наук, професор, \\ Київський національний університет культури і мистецтв, \\ Київ, Україна \\ https://orcid.org/0000-0002-3365-7266, \\ olexkurodamail.com
}

\begin{abstract}
Мета статті - ввести до наукового обігу й узагальнити нові матеріали, які дозволяють ближче ознайомитись із традиційними весільними танцями українців. Методологія. Дослідження проведене на основі міждисциплінарного підходу, шляхом системного аналізу літературних, документальних, етнографічних і фольклорних матеріалів. Наукова новизна. Здійснено першу спробу визначити ролі, функції та семантику обрядових танцівігор як невід’ємної частини традиційного весільного ритуалу українців. Висновки. Місце і значення танцю у весільному ритуалі українців на сьогодні досліджено ще недостатньо. Весільні танці правомірно розділити на дві групи: обрядові та необрядові. Останні належать до художніх явищ пізньої формації, вони не пов’язані з генезисом і структурою ритуалу й можуть входити до програми різноманітних святково-розважальних заходів і подій. Натомість обрядові танці-ігри, розглянуті в цій розвідці, належать до більш глибоких шарів народного побуту й культури і становлять органічну й структурно-утворюючу домінанту весільного дійства. Яскраво проглядає в них первісна синкретична природа народного мистецтва, де танець тісно переплітається з іншими видами мистецтв: драмою, пантомімою, співом, музикою, грою, публічними розвагами. По суті, мова йде про уламки обрядової хореї - магічного танцю-співу-гри, що дожили подекуди в традиційному середовищі до XXI ст. Розглянута група танців («Журавель», «Зайчик», «Танці на рядні», «Чоботи») відрізняється національною самобутністю, яскравістю, екзотичністю, карнавальною свободою і гумором. Разом з тим їх характеризує громадська значимість, націленість на виконання важливої соціальної місії - єднання родового колективу. Обрядові танці-ігри потребують подальшого вивчення із застосуванням сучасних методів і прийомів науки етнохореології.
\end{abstract}

Ключові слова: танець, гра, обряд, весілля, карнавальний сміх, сороміцький фольклор, хореографічна традиція. 


\section{ОБРЯДОВЫЕ ТАНЦЫ-ИГРЫ - МАЛОИССЛЕДОВАННЫЕ КОМПОНЕНТЫ ТРАДИЦИОННОЙ СВАДЬБЫ УКРАИНЦЕВ}

\author{
Курочкин Александр Владимирович, \\ доктор исторических наук, профессор, \\ Киевский национальный университет \\ культуры и искусств, \\ Киев, Украина, \\ https://orcid.org/0000-0002-3365-7266, \\ olexkurodagmail.com
}

Цель статьи - ввести в научный оборот и обобщить новые материалы, которые позволяют ближе познакомиться с традиционными свадебными танцами украинцев. Методология. Исследование проведено на основе междисциплинарного подхода, путем системного анализа литературных, документальных, этнографических и фольклорных материалов. Научная новизна. Впервые осуществлена попытка определить роли, функции и семантику обрядовых танцев-игр как неотъемлемой части традиционного свадебного обряда украинцев. Выводы. Место и значение танца в свадебном ритуале украинцев сегодня исследовано еще недостаточно. Свадебные танцы правомерно разделить на две группы: обрядовые и необрядови. Последние относятся к художественным явлениям поздней формации, они не связаны с генезисом и структурой ритуала и могут входить в программу различных празднично-развлекательных мероприятий и событий. Зато обрядовые танцы-игры, рассмотреные в нашей разведке, принадлежат к более глубоким слоям народного быта и культуры и составляют органическую и структурно-образующую доминанту свадебного действа. Ярко просматривается в них начальная синкретическая природа народного искусства, где танец тесно переплетается с другими видами искусств: драмой, пантомимой, пением, музыкой, игрой, публичными развлечениями. По сути, речь идет о обломках обрядовой хореи - магического танца-пения-игры, доживших кое-где в традиционной среде до XXI века.

\section{RITUAL DANCE-GAMES - LITTLE EXPLORED COMPONENTS OF UKRAINIAN TRADITIONAL WEDDING}

\author{
Oleksandr Kurochkin, \\ Doctor of Historical Sciences, Professor, \\ Kyiv National University \\ of Culture and Arts, \\ Kyiv, Ukraine, \\ https://orcid.org/0000-0002-3365-7266, \\ olexkurodamail.com
}

The purpose of the article is to introduce into scientific circulation and summarize new materials that allow you to get acquainted with the traditional wedding dances of Ukrainians. Methodology. The study was conducted on the basis of an interdisciplinary approach, through a systematic analysis of literary, documentary, ethnographic and folklore materials. Scientific novelty. For the first time, an attempt was made to determine the roles, functions and semantics of ritual dance-games as an integral part of the traditional wedding ceremony of Ukrainians. Conclusions. The place and importance of dance in the wedding ritual of Ukrainians today has not been studied enough. Wedding dances can rightfully be divided into two groups: ceremonial and non-ceremonial. The latter relate to the artistic phenomena of the late formation, they are not related to the genesis and structure of the ritual and may be included in the program of various festive and entertainment events and proceedings. But the ceremonial dance-games considered in our intelligence belong to the deeper layers of folk life and culture and make up the organic and structurally-forming dominant of wedding action. The initial syncretic nature of folk art is clearly visible in them, where the dance is closely intertwined with other types of arts: drama, pantomime, singing, music, playing, public entertainment. In fact, we are talking about the fragments of ritual chorea - magic dance-singing-games, which have survived here and there in the traditional environment until the 21st century. The considered group of dances («Zhuravel», «Zaichyk», «Tantsi na riadni», «Choboty») is distinguished by 
Рассмотренная группа танцев («Журавель», «Зайчик», «Танци на рядни», «Чоботы») отличается национальной самобытностью, яркостью, экзотичностью, карнавальной свободой и юмором. Вместе с тем их характеризует общественная значимость, нацеленность на выполнение важной социальной миссии - соединения родового коллектива. Обрядовые танцы-игры требуют дальнейшего изучения с применением современных методов и приемов науки етнохореологии.

Ключевые слова: танец, игра, обряд, свадьба, карнавальный смех, срамной фольклор, хореографическая традиция. national identity, brightness, exoticism, carnival freedom and humor. At the same time, they are characterized by social significance, a focus on fulfilling an important social missionuniting the clan collective. Ritual dance-games require further study using modern methods and techniques of the ethnochoreology science.

Keywords: dance, game, rite, wedding, carnival laughter, Soromitskyi folklore, choreographic tradition.

Актуальність теми дослідження. Незважаючи на тривалу історію вивчення, традиційна весільна звичаєвість українців заховує в собі ще чимало прогалин і нез'ясованих питань. Це стосується, зокрема, другої, так званої перезвянської частини весілля (після обряду комори), коли сувора й урочиста церемонія шлюбного зближення двох родів набуває яскраво пародійного звучання, перетворюється на розважально-сміхове дійство, де панує стихія карнавальної свободи, невимушеності, емоційного розкріпачення.

Брак належної уваги до розважально-ігрового компонента традиційного весілля - давня вада вітчизняного народознавства. Свого часу її помітив і спробував пояснити Хведір Вовк. Характеризуючи у класичній праці вакхічну атмосферу перезви, коли в хаті молодого горілка ллється рікою, жінки співають «найцинічніших пісень» і нарешті розпочинаються «несамовиті танці», автор робить характерну ремарку: «На жаль, українська етнографія майже не має потрібних матеріалів для вивчення цієї частини весільних звичаїв, хоча якраз ця частина дуже важлива і вивчення її мало б кинути світло на найстародавніші та найцікавіші риси культу й звичаїв у примітивних слов'янських народів і дати пояснення фактам, що й досі зостаються для нас незрозумілими» (Вовк, 1995, с. 302).

Такий стан речей, на думку Хв. Вовка (1995), був обумовлений, з одного боку, «соромливістю етнографів», що працювали над цим питанням, а з іншого - «суворістю російської цензури...» (с. 302). Названі причини були оприлюднені на сторінках французького журналу «L’Antropologie» у 1891 р., але фактично вони не втратили своєї актуальності й для наступних часів. Так, у 20-х роках XX ст. академік М. Грушевський (1993), солідаризуючись із Хв. Вовком, мусив визнати, що на перешкоді дослідження оргіастичного елементу весілля «ставали і цензурно-політичні заборони і власна пріодерія збирачів» (с. 276).

Ситуація не змінилась на краще й після жовтневого перевороту, коли вже радянською цензурою із класово-ідейних міркувань методично ігнорувалися й засуджувалися архаїчні селянські традиції, свідомо елімінувався еротичний складник народної культури і фольклору. Через названі причини цілий пласт обрядових 
розваг весільної перезви набув сумнівної слави «некультурних», «непристойних», «сороміцьких».

Аналіз останніх досліджень і публікацій. Кардинальні зміни у підходах науковців-гуманітаріїв до табуйованих раніше тем стали можливими лише після краху СРСР і всієї системи тоталітарного ідеологічного контролю. У 1990-х роках, із великим запізненням, розпочався процес поступового заповнення істотних лакун у вивченні традиційного весілля, на які слушно вказували цитовані вище Хв. Вовк і М. Грушевський. Певний внесок до розкриття обговорюваної проблематики здійснив і автор цих рядків (Курочкін, 2004a; 2004b; 2009; 2015; 2016; 2017).

Джерельну базу цього дослідження складають окремі наукові публікації й доволі репрезентативний фактаж польових експедицій останніх десятиліть, зібраний науковцями Інституту мистецтвознавства, фольклористики та етнології ім. М. Т. Рильського Академії наук України.

Мета статті - увести до наукового обігу й узагальнити нові матеріали, які дають змогу ближче ознайомитись із традиційними весільними танцями українців, які Хв. Вовк назвав «несамовитими».

Виклад основного матеріалу. У фокусі нашої уваги чотири хореографічноігрові комплекси весільного перезвянського циклу: «Журавель», «Зайчик», «Танці на рядні», «Чоботи». Враховуючи варіативну природу фольклорних традицій, спробуємо дати етнокультурну характеристику названих танців-ігор, розкриваючи їхню семантику і функції у святково-обрядовому контексті. Сучасне вивчення народних танців вимагає спеціальної методики й точного запису кожного руху виконавців. Цю відповідальну місію залишаємо для зацікавлених фахівців-хореографів.

«Журавель» («Бусел»). Первісні танці виконувалися переодягнутими акторами в масках, які старанно імітували поведінку окремих звірів і птахів. 3 часом елементи рядження зникали, але актори продовжували засобами хореографії й пантоміми створювати образи зображуваних персонажів. Подібну еволюцію, ймовірно, пережив і архаїчний весільний танець «Журавель».

Взагалі, зооморфна масканадзвичайнопопулярна наєвропейськомуконтиненті.Цікаво,що одині той же образ відповідно вбраного актора, котрий носить пташину голову з довгим дзьобом, як помітив К. Мошинський (Moszynski, 1968), в одній частині України (Схід і південний Захід) вважається журавлем, тоді як у північнозахідному регіоні, а також у Польщі - боцяном (лелекою) (с. 295). Семантична подібність, а часом і взаємозамінність обох названих перелітних птахів простежується й на матеріалах обрядової хореографії.

Найбільш ранні згадки про весільного боцяна-журавля знаходимо в мандрівних записках шведського посла Конрада Гільденбрандта, який у 1656-1657 роках відвідав Україну. Під'їжджаючи до гетьманської столиці - Чигирина (сучасна Черкащина), він зустрівся з гуртом веселих підпилих жінок в овечих кожухах, які, пританцьовуючи й падаючи на сніг «співали про бузька та інші любовні справи» (Олянчин, 1937, с. 54). Усі деталі цього повідомлення виглядають дуже достовірно і не залишають сумнівів у тому, що зображується типова ситуація перезвянського ігрища на другий день після обряду «ламання калини».

Танець «Журавля» згаданий у бурлескно-травестійній поемі «Енеїда» І. Котляревського (1982) (кінець XVIII ст.) в описі розваг, влаштованих Дідоною на честь 
троянців: «Тут інші журавля скакали. А хто од дудочки потів» (с. 44). Важливі подробиці щодо звичаю подав у коментарях до своєї «Истории Малой России» (перше видання у Москві 1822 р.) Д. Бантиш-Каменський. По-перше, дослідник спостеріг, що «Журавля» починають «вести» після встановлення факту цнотливості нареченої (обряд комори - О. К.) (Бантыш-Каменский, 1993, с. 593). По-друге, він стисло охарактеризував саме дійство: «Всі гості беруться міцно за руки, танцюють і співають:

Та внадився журавель,

Та до наших конопель,

Таки, таки цибатий,

Таки, таки носатий

(Бантыш-Каменский, 1993, с. 593).

По-третє, історик відзначив «недобропристойність» подальших куплетів цитованої пісні, звинувативши в цьому «п’яних бабів» (Бантыш-Каменский, 1993, с. 593).

Цікава, але дуже скупа інформація Д. М. Бантиш-Каменського (1993) про весільного «Журавля» може бути доповнена завдяки працям українських етнографів і фольклористів XIX-XX ст. На підставі цих даних можна стверджувати, що образ журавля-боцяна, крім весілля, зустрічається в різних ритуальних циклах українців: різдвяно-новорічному, великодньому, поховальному («ігри при мерці»), родильно-хрестинному тощо. Мотив журавля популярний у календарних (особливо весняних) піснях простежується в інших розділах і жанрах пісенного, музичного фольклору, в ігровому репертуарі дітей і дорослих.

Ареалом стійкого збереження весільного «Журавля», де він дожив до XX ст., слід вважати Середнє Подніпров’я, зокрема Черкащину. До речі, саме тут фіксуються й інші обрядові архаїзми, невідомі або забуті на інших українських територіях. Якісний запис ігрового церемоніалу «плетіння журавля» належить С. Терещенковій. Він був здійснений у 1920-х роках у с. Попівка Звенигородського p-ну. Тут, як свідчить С. Терещенкова, із «журавлем» ходили у вівторок по обіді, того ж самого дня, коли зранку переодягалися на «циганів» і сходилися на «кури». «За “журавля”, - повідомляє вона, - стає найдотепніший боярин. За його одежу береться хто-небудь з весільних, а за того ще хто, і так одно за друге. Набереться величезний ключ “журавлів” - чоловіків та жінок; от вони йдуть, і співають “журавля”, і крукають. Таким чином вони йдуть по селу, і держаться міцно один одного, бо хто одірветься, то мусить дать горілки, - тому вони держаться, куди б “журавель” не вів. “Журавель” веде найтруднішими стежками, проваллями, через рови, будяки, тини, воду. А найбільше люблять ходити через якусь будівлю. Для “журавля” селяни показують щонайкрутіші шляхи. От, у кого висока клуня, то каже: “А переведи через мою клуню - горілка буде!” “Журавель” веде на клуню...» (Кримський, 2009, с. 132).

У деяких селах Звенигородщини досліджуваний звичай дожив до 80-х років XX ст. Про це повідомив наш інформатор із с. Чичикозівка П. Филипенко (1910 р. н.): «“Плести журавля” йдуть всі, хто гуляє на свадьбі. Беруться за руки, 
танцюють. А такий Артюха був, на хату виліз, рядном комина закрив, дим у хату. А кухарка каже: “Не до добра журавель на комін сів”» (Курочкін, 1990).

Одинадцятитомний «Словник української мови» визначає танець «Журавель» як «народний сюжетний танець, в якому танцюючи зображають журавля» (“Журавель”, 1971, с. 547). Це слушна, але неповна характеристика. Означений танець можна визначити також як хоровод («корогод»), основною формою якого був ланцюг взаємопов’язаних учасників, що рухались по колу або змієподібно, прямою лінією, завивалися спіраллю тощо. «Журавель» міг бути і незамкнутим у формі журавлиного ключа. Основна вимога до учасників танцю - колективізм, злагодженість рухів у повній відповідності до ігрової програми, яку задає вигадливий і досвідчений вожак - протагоніст веселого гурту. Синхронізувати дії під час «плетіння журавля» допомагали різноманітні способи зв’язку танцюристів: за руки, під руки, за плечі, за пояси, за одежу тощо. Тут доречно згадати і вказівку Хв. Вовка (1995) про те, що даний танець - «це рід кола, болгарського хоро, виконання якого супроводять ріжними еротичними рухами, як наприклад, хапання один одного за pudenda (сороміцькі місця - О. К.)» (с. 303).

Цікаві подробиці щодо режисури й пластики рухів досліджуваного танцю знаходимо в описі весілля в містечку Дубовій Уманського повіту на Київщині, датованому початком ХХ ст. «По обіді старости, - повідомляє респондент, - виводить 3-за столу молодого, а дружко молоду на двір до музик і там їх під музику викручують. Викручуванє робить ся так: як тілько молодих виводять на двір, музики починають грати танець: “Як ходив журавель, журавель” або який інший. Староста подає кінець своєї хусточки молодому, а дружко молодій і пройшовши так кілька кругів танцю, роблять над головою молодих круг справа на ліво; староста і дружко роблять круг, а молодий і молода тричі перекручуються так, щоб за кождим разом стояли лицем до старости й дружка. Як молодих викрутять, вони начинають танцювати польку, при чім ані дружки, ані світилки, ні бояри не танцюють в цей час, коли молоді танцюють, аж як кончать танцювати молоді, тоді вже танцюють всі, хто хоче. Молода гуляє у молодого до самого полудня» (Гнатюк, 1919, с. 68-69).

Неприкритий натуралізм досліджуваного танцю-гри яскраво ілюструють і наші матеріали із придніпровського с. Білозір'я (Черкаського р-ну і обл.). Тут «Журавля» водили в той день, що називається «кури», і робили це в такий спосіб: дядько великого зросту брав між ногами голоблю чи довгу палицю, чіпляючи до неї два буряки (гротескова імітація чоловічого статевого органу), позад нього на голоблю сідали верхи ще 5-6 жінок - свах. У такому порядку супроводжувана сміхом і приперченими жартами процесія з підскоками і вихилясами мала тричі обійти намет, де обідали учасники весільного бенкету (Курочкін, 1990).

Обговорюваний танець-гра немовби був спеціально створений для вільного спілкування обох статей за умови вакхічного збудження, викликаного колективним вживанням спиртних напоїв. Під час його виконання дозволялися жести й поведінка, які в інший час були б оцінені як відверто аморальні й непристойні. Варто наголосити, що подібні сплески «сексуальної свободи» були не винятком чи аномалією, а вважалися обов'язковим компонентом успішного проходження шлюбного ритуалу. Етнограф ХІХ ст. М. Маркевич (1991) чітко підкреслив, що весільна процесія, де танцюють і співають «Журавля», буває лише тоді, «як молода чесна» (с. 142). 
3 погляду науки цікаво з'ясувати еротичне підгрунтя танцю-гри «Журавель». Усе вказує на те, що цей птах став весільним символом зовсім не випадково. Уважно вивчаючи світ навколишньої природи, наші предки, очевидно, звернули увагу на цікаві шлюбні танці журавлів, що відбувалися навесні й на початку літа. Зібравшись десь на рівному майданчику, зграя пернатих утворювала коло, в середину якого по черзі виходило кілька особин, щоб своєрідними скоками, помахами крил і трубними звуками привабити до себе шлюбного партнера. У народних уявленнях українців журавлі, що ведуть моногамний спосіб життя, зажили слави взірцевого подружжя (Курочкін, 2004b).

«Зайчик». До архаїчних елементів весільного дійства слід віднести й обрядовий танець-гру «Зайчик». Територія його побутування спеціально не досліджувалася. За нашими (далеко не повними) даними, вона охоплювала основний масив земель Середнього Подніпров’я (Південна Київщина, Черкащина, Кіровоградщина, Дніпропетровщина). Танець-гра зазвичай уходив до програми традиційних забав весільного понеділка, у якій домінували життєрадісні, оргіастичні мотиви. За свідченням наших інформаторів, він міг відбуватися і в хаті, і на подвір'ї. Спочатку свекруха і свекр, а за ними й інші учасники гостини, хто бажав, виконували кумедні підскоки, зводячи й розводячи ноги над двома схрещеними рогачами, покладеними на землю або підлогу. Подекуди один з рогачів заміняла кочерга (коцюба) чи пікна лопата. Стрибаючи, виконавці намагалися не збити й не зачепити ці інструменти хатнього начиння. Той, кому це не вдавалося, зазнавав покарання через вимазування обличчя сажею.

Танець був своєрідним тестом на ступінь сп'яніння: його нескладні рухи підкорялися лише тим, хто міцно тримався на ногах. Ігровий епізод жартівливого випробовування створював ситуацію невимушеного святково-сміхового спілкування, у яку втягувалися всі присутні. За повір'ями, цей танок мав забезпечити новостворену сім’ю дітьми та сприяти сексуальній потенції чоловіка.

Під час стрибання чергового «зайця», весільні гості співали, плещучи в долоні:

А у полі гречка процвітає.

А в долині зайчик чибиряє.

Ой якби я такі ніжки мала (мав)

То й я як зайчик чибуряла (чибуряв)

(Курочкін, 1982).

У деяких локальних традиціях «Зайчик» включали до свого репертуару весільні «цигани», що ще більше посилювало гумористичний колорит танцю. Канонічний текст супровідної пісні ряджені доповнювали своїми власними імпровізаціями:

Ой у полі мак розцвітає,

А в долині зайчик чибиряе.

Якби я такі ніжки мала

Як той зайчик чибиряла.

Дяк пішов до Хими,

Та й питає,

А чи Хима дома, 
Чи немає,

Хить-мить

Коло Хими бряскотить

Хитя-митя та й чує

Вона дома не ночує

Раз, два, три ...

(Курочкін, 1991).

Як і «Журавель», досліджуваний танець-гра не є приналежністю лише весільного ритуалу. На тій же території Наддніпрянщини та на землях сусіднього Поділля фіксується його побутування в різних ситуаціях: календарні, родинно-побутові свята, молодіжні вуличні зібрання тощо. Зокрема, у ряді сіл Південного Поділля (Вінничина) нами простежений факт присутності танцю «Зайчик» або «Чотири дірки» в новорічному ритуалі «Маланка». Під час традиційних обходів дворів у ніч із 13 на 14 січня один з ряджених «циганів» танцював над двома перехрещеними на землі палицями - «ключками». Він високо підстрибував, почергово перехрещуючи ноги й намагаючись не порушити палиць. Як і весільний, новорічний танець мав спеціальну супровідну пісню аграрного спрямування, у якій згадувалися різні сільськогосподарські культури: жито, гречка, ячмінь та ін. Більш-менш повний варіант цієї пісні нам вдалося записати в с. Червона Гребля Чечельницького р-ну Вінницької області. Ось фрагмент із нього:

Ой на горі жито.

Ой на горі жито.

Сидить зайчик.

Він ніжками чеберяє.

Якби такі ніжки мала,

То я б ними чеберяла,

Як той зайчик,

Як той зайчик.

Ой на горі гречка...

(Курочкін, 1988).

Присутність аналогічного танцю із супровідною піснею і в структурі новорічного, і весільного ритуалу - важливий показник давності народного звичаю. Синхронне побутування архаїчного танцю-гри «Зайчик» у календарній (колядній) і весільній традиції простежене також за матеріалами Рівненського Полісся. Щоправда, тут він був не сольний, а гуртовий: під час коляд його виконували в обряді «Водіння короля» великою кількістю пар танцюристів по колу; гуляючи на весіллях, «бігали то в одну, то в другу сторону» (Прохорчук, 1996, с. 66).

Можна думати, що ритуальний танець «Зайчик», як і інші хореографічні малюнки подібного ряду, первісно імітував поведінку й рухи відповідної тварини. Але 3 часом буквальні наслідувальні жести ускладнювалися і трансформувалися завдяки новим символічним значенням. Істотну роль при цьому відіграв характерний для розвитку народної творчості процес антропоморфізації фольклорних персонажів. У такому метафоричному ключі образ «зайчика» трактують тексти 
дохристиянських весняних хороводних ігор. У варіанті, записаному О. Волошиним та О. Басистою в 1938 р. на Поділлі, «зайчик» явно осмислюється як парубок, котрий шукає собі наречену:

Ой ти, зайчику-бідолайчику,

Ти полинь, полинь до Дунайчику.

До Дунаю води пити,

До Корпа дівку любити.

«Зайчик» показує, як він пливе, томиться, i, нарешті, «підпливає» до дівчини, яку хоче взяти в круг (Волошин, 1960, с. 49).

Наведені нами фольклорні приклади засвідчують органічний зв'язок образу зайця з архаїчним пластом землеробської ритуалістики і світогляду, що мав свою міфологічну основу. Різні форми й семантичні аспекти відображення цього образу в слов'янській культурі детально розглянуті у спеціальних працях О. Гури $(1978 ; 1997)$. Переконливо розкривається в них міфологічна співвіднесеність мотиву зайця з любовно-шлюбною тематикою, еротичною (фалічною) символікою та демонічним світом. Охарактеризована нами вище пантомімічна весільна і календарна гра-танок також добре узгоджується з цією концепцією. Вірогідно, не випадкова і зафіксована в текстах обрядової пісні асоціація образу зайця з гречкою, що цвіте. Ця давня землеробська культура в українській фольклорній традиції і в літературі нерідко осмислюється як еротичний символ. Звідси відомий фразеологізм - «скакати (стрибати) в гречку» на означення статевих позашлюбних зв'язків.

На підставі всього обсягу наведених вище фольклорно-етнографічних даних можна твердити, що семантичне навантаження образу зайця в системі міфологічного світогляду слов'ян було доволі широким і включало в себе і еротичний аспект, і аспект аграрної магії. Подібна символічна амбівалентність $\epsilon$ цілком закономірною, оскільки пояснюється архаїчними уявленнями про взаємозв'язок родючості землі та людини. Отже, «плетіння журавля» і стрибки весільного «зайчика», по суті, дублювали одне одного й були рівнозначними у плані давньої семантики. Первісно вони виконували загальну прокреативну (породжувальну) функцію, належачи до розряду господарсько-магічних та еротичних танців, покликаних стимулювати продуктивність селянських ланів і дітонародження як логічний результат шлюбної церемонії.

Розглянуті вище танці-пантоміми належать до глибинних шарів традиційної культури. Важливий уже сам принцип зоорнітономінації, який виражає особливе поважне ставлення до тварин і птахів, характерне для ранніх форм релігії (тотемізм, промисловий культ, шаманізм тощо).

Дві інші хореографічні композиції, про які піде мова далі, належать до пізнішої стадії народного світогляду й ритуалістики. Вони пов’язані із процесом становлення сільської общини, моногамного шлюбу і сім'ї. Функціонування цих інститутів у традиційному суспільстві було жорстко детерміноване чинниками соціально-економічного порядку.

Танці на рядні, окрім розважально-ігрової, виконували важливу інтегруючу функцію об’єднання сімейно-родового колективу, налагодження взаємозв'язків 
між представниками різних вікових генерацій, маніфестували споріднення кланів молодого й молодої. 3 повним правом ці танці-ігри можна визначити як «почесні», оскільки вони наголошували ієрархічний статус усіх членів святкового дійства.

Зазвичай «танці на рядні» відбувалися в понеділок чи вівторок у зв’язку з обрядом перепою (поділу короваю) та обдарування молодих. Через значну редукцію традиційного весільного ритуалу в останні десятиліття цей звичаєвий комплекс нерідко переноситься на неділю.

Важливо одразу пояснити, чому колективний весільний танець відбувався (а часом і відбувається) не просто на землі або підлозі, а на простеленому рядні. Це явна ознака обряду і вияв пошани до його учасників. Подібну мотивацію має звичай, коли, зустрічаючи високих гостей, покладають червоний хідник або килимову доріжку під час дипломатичних прийомів або на церемоніях відкриття престижних фестивалів.

Рядно - груба конопляна тканина, з якої селяни виготовляли простирадла, ковдри, доріжки тощо. У народній культурі українців рядно, як і полотно, - символ багатства й добробуту. Під час весілля його використовують як важливий обрядовий атрибут багатофункціонального призначення. Рядно готували заздалегідь, зшиваючи кілька смуг у велике полотнище, що мало служити танцювальним майданчиком. Нерідко ряджені «цигани» чи інші ентузіасти заради сміху приносили на рядні до весільної оселі тих родичів і сусідів, які чомусь запізнювалися, вимагаючи за цю роботу могорич. За певну винагороду кілька дужих чоловіків пропонують погойдати на рядні. У цьому ігровому атракціоні можна побачити символічний сенс - побажання молодим невдовзі гойдати у колисці свою дитину.

У народній свідомості танці на рядні вважалися запорукою щасливого шлюбу. Закликаючи весільних гостей до цього обрядодійства, свахи співали: «На рядно, родинонько, на рядно, на рядні добре сидіти, щоб наші любилися діти».

Під час виконання колективного танцю підпилі глядачі умисно виливали на рядно кілька відер води й кидали землю або пісок, внаслідок чого утворювалося справжнє болото. Грязюка, багно - весела матерія, пов'язана з вегетативною силою та магією родючості. В атмосфері святкового інобуття добровільне забруднення - не просто вульгарна розвага, а свідомо карнавальна поведінка. За інформацією респондентів з різних локальних осередків, на брудному рядні танцювали, по ньому качалися, ним обгортали окремих гостей, у ньому колихали, вимагаючи за це винагороду. За даними Хр. Ящуржанського (1896) кінця XIX ст., у Єлизаветградському повіті рядно використовували у весільних забавах, споруджуючи для молодят гротескну хату-намет, куди заводили на хазяйство кота, собаку і півня (с. 40).

Одне з ранніх свідоцтв про використання рядна у весільній обрядовості знаходимо в етнографічному описі О. Гриші з Гадяцького повіту Полтавщини. У танцях на рядні, які відбувалися тут, на другий день після першої шлюбної ночі, провідну роль відігравали почесні чини з боку молодого. «Як прийдуть молоді із церкви до дому, то зараз, - повідомляє Он. Гриша (1899), - водять люде молоду танцювати: візьмуть де небудь бояре рядно, поллють його водою і тоді візьме один боярин молоду за руку, тай танцює з нею по рядні; як потанцює той боярин з молодою, то мусить викинути на тарілочку дружкові грошину (дружко стоїть 3 тарілочкою, там де молода танцює). А далі бере молоду другий боярин, теж потанцює з нею, 
так же саме і третій боярин теж потанцює з нею. Після бояр танцюють по одинці усі люде, так як і бояри потанцювали» (с. 246).

Наведений опис по-своєму унікальний. Він фіксує ситуацію, коли в танцях на рядні були активно задіяні молода і бояри. Це відгомін архаїчного права всіх чоловіків роду на молоду. Пізніші документальні свідоцтва XX-XXI ст. вже не згадують бояр як учасників конкретного весільного епізоду, що, очевидно, пов’язано з історичною трансформацією і спрощенням самого ритуалу. До цього слід додати, що традиція, коли наречена була забов'язана протанцювати з усіма весільними гостями чоловічої статі, відома багатьом європейським народам.

Особливу цінність для нас має детальний опис досліджуваного весільного звичаю, зроблений 1926 р. у с. Попівка на Звенигорідщині досвідченим етнографом С. Терещенковою. Вона повідомляє: «Роздарувавши коровай, устають 3-за столу, стелять нове молодої рядно на долівці, і танцюють тещи із свекром, а тесть із свекрухою на рядні. Грачі грають, а вони приспівують...» (Кримський, 2009, с. 129). Ритуальний танець батьків завершує виразна сміхова мізансцена: «Одспівавши пісню, всі тії танцюристи попадають на рядні і лежать. I зять їх «одлива»: частує горілкою, і тоді вони встають» (Кримський, 2009, с. 129).

Після батьків на рядні танцюють всі весільні гості, і кожен, перетанцювавши, кидає на рядно гроші для молодої, яка має його випрати у наступні дні.

3 того ж етнографічного опису дізнаємося, що на рядні виконувалися різні танці. Слідом за батьками перша пара танцювала «Чумака». Ось як кореспондентка характеризує цю ігрову сценку: «Молодиця - “чумакова жінка” вдає, що вона ображається і сердиться на “чумака”, і весь час вона, як танцює, то одвертається од нього, а “чумак”, буярин той, танцюючи ловить іï, щоб зазирнути в очі, i танцює скинувши шапку, ніби перепрошує. І так у танцях вони красивенько собі вихиляються. Коли вона, “чумакова жінка”, помириться, то поцілується з ним, і тоді “чумак” швидко навприсядки танцює, а вона його догонить, нагнувшись танцює і робить гарненькі вихиляси головою й руками. До цього танцю грачі грають “Чумака”, і всі хто є в хаті приспівують:

Чумакова жінка гуляє,

Бо чумака вдома немає.

Гуляй, гуляй, чумакова жінка

Од середи аж до понеділка

(Кримський, 2009, с. 129).

За «Чумаком» бояри попарно з молодицями танцювали на рядні «Козак», супроводжуючи його колективною піснею:

Катерина гречку в’язала, Катерина правду казала.

В Катерини чорнії очі, Катерина добра до ночі...

(Кримський, 2009, с. 130).

Прикметно, що, виконуючи ритуальний танок, додержувалися вікової субординації. Останніми на імпровізований кін виходили старі діди, які, кумедно перебираючи ногами, приспівували: 
Ой піду я в понеділок -

Та проп’ю я сім кудільок.

Сам п’ю, сам гуляю,

Сам стелюся, сам лягаю!

Ой піду я у вівторок...

(Кримський, 2009, с. 130).

У такій редакції весільний обряд виглядає як справжня народна вистава синкретичного характеру, у якій танець, спів, музика поєднуються з мімікою і пластикою рухів виконавців. Окремі деталі наведеного опису можуть стати в нагоді сучасним постановникам хореографічних композицій на професійній і самодіяльній сцені.

На рядні танцювали, як правило, парами. Подекуди ті гості, які не мали пари, мусили танцювати 3 кочергою або з вилами, що надавало дійству яскраво гумористичного забарвлення. За відомостями інформаторів, у перезвянських забавах домінували народні танці, такі як «Гопак», «Козачок», «Полька», «Коробочка», «Карапет» та ін. Модні танці, звичайні для молодіжних зібрань, для цієї звичаєвої ситуації не підходили. Представники старшого покоління зневажливо визначають їх як «фіглі-міглі».

Не можна обминути увагою своєрідний музичний супровід танців на рядні. Фахових виконавців-музик звичайно наймали на першу урочисту частину весілля (до розподілу короваю), у другій же, виразно оргіастичній, частині віддавали перевагу підручним акустичним засобам. Так звана «самодіяльна музика» в різних локальних осередках називалася: «бабська», «своя», «тюки-гуки», «грати на віник», «грати на язик» тощо. Поруч із примітивними шумовими пристроями з хатнього начиння (качалка, рубель, заслінка від печі, ложки, каструля, відра тощо) активно застосовувалися можливості людського тіла (ляскання пальцями, плескання в долоні, тупіт ногами). Створенню галасливої какафонії сприяли також гра на гребінцях, спонтанні вигуки, виконання приспівок до танців з обсценними (обсценний - від анг. obscene - непристойний, соромітний) та еротичними мотивами і жартівливих пісень a'capella. Широке розповсюдження в народі мало повір’я: «Чим більше шуму і сміху на весіллі, тим щасливішим буде життя молодих».

Досліджуваний обряд виконував і певну меркантильну функцію. Зазвичай на рядно танцюристи кидали дрібні гроші, які мали разом збирати молоді. У деяких локальних традиціях цей акт виглядає як весела гра - молодята змагаються в тому, хто збере більше грошей. Переможця жартівливо проголошували главою новоствореної сім'ї. Окремі виконавці, щоб насмішити й показати свою вправність, танцювали на рядні босоніж, затиснувши між пальцями ніг монети. Фокус полягав у тому, щоб утримати монети в танці якомога довше. В останні десятиліття, у зв'язку з поширенням міських стандартів, і в селах все частіше відмовляються від дарування на весіллях речей і дрібних грошей, а натомість переходять до вручення молодим конвертів з грішми.

Варто наголосити, що й після завершення танців брудне рядно продовжувало виконувати роль обрядового атрибута. Часто-густо, за давнім звичаєм, активні свахи обляпували ним побілений комин печі або стіни хати знадвору (ліквідувати цю шкоду мала невістка). У багатьох місцевостях веселий гурт підпилих гостей влаштовував колективне пародійне прання рядна на річці або ставку. Тут же могло відбу- 
ватися і ритуальне купання батьків і їх переодягання в новий чистий одяг. Нерідко при цьому застосовували прийом жартівливої травестії: на батька одягали жіночу сорочку, а на матір чоловічі штани або труси тощо. Сміховий ефект цього дійства багато в чому залежав від імпровізаційних здібностей самих учасників.

На Смілянщині побутує звичай, згідно з яким боярин (дружко) після прання мав украсти рядно й закинути його на дах. Якщо комусь із веселян вдавалося непомітно зробити це раніше, боярину належало поставити йому могорич (Курочкін, 2011). Заслуговує на увагу і той факт, що випране весільне рядно заведено зберігати як реліквію-оберіг новоствореної сім'ї.

«Чоботи». У багатьох локальних варіантах весільного дійства «Танці на рядні» помітно виокремлюється хореографічно-драматичний обряд «Чоботи». За нашими спостереженнями, він нерідко заступає вульгарні й примітивні веселощі з рядном, які зі зміною поколінь швидше виходять з ужитку.

Специфіка обрядового танцю-гри «Чоботи» в тому, що він маніфестує єднання двох родин через безпосередню комунікацію молодого з матір’ю молодої, зятя із тещею. Ці побутові стосунки, яскраво відображені в українському фольклорі, мають суперечливий, амбівалентний характер. 3 одного боку, зять виявляє велику шану до матері своєї обраниці:

Мені батько не рідня, Мені мати не рідня, Мені теща родина, Мені жінку народила.

3 іншого боку, тещі боялися і застерігалися від неї як представниці чужого роду. Такими повір'ями пояснюється весільний звичай, який дожив до наших днів, переводити тещу через багаття, коли вона вперше заходила на подвір'я молодого. В міру того як народний світогляд звільнявся від давніх страхів і забобонів, демонічний образ тещі втрачав свої негативні конотації, перетворюючись поступово на комічну постать - зручну мішень побутових жартів. Реальним підтвердженням цієї трансформації може служити багатий арсенал анекдотів про взаємини тещі й зятя, активно побутуючий сьогодні і в сільському, і в міському середовищі.

Весільний звичай українців - дарувати тещі чоботи від зятя - можна тлумачити як пережиток давньослов'янського віна - плати за наречену. Водночас цей звичай засвідчує доволі високий статус жінки-матері в системі родинних зв'язків. У традиційному селі, де влітку часто ходили босоніж, а взимку в личаках і постолах, шкіряні чоботи вважалися коштовною річчю і престижним даром. Про цей дар в окремих місцевостях спеціально домовлялися на етапі сватання і заручин: наявність або відсутність його прямо корегувалася з кількістю родичів у поїзді молодого. Дещо подібний звичай відомий і в болгар. Плата за наречену має в них назву обучта (oboutchta), цебто взуття (Вовк, 1995, с. 268).

За давньою традицією, після першої шлюбної ночі, переконавшись у цнотливості молодої, зять разом з боярами йшов дякувати ї̈ батькам. При цьому нерідко тестю вручали символічну «борону» 3 тіста, а тещі такий же «праник» як своєрідну компенсацію за відхід з дому дочки - робітниці. 
У багатьох етнографічних описах весілля з Наддніпрянщини й сусідніх регіонів у якості подарунків батькам молодої згадуються чоботи та рукавиці. Отримавши й одягнувши їх, теща і тесть по черзі танцювали в супроводі присвяченої цій події жартівливої пісні. Коли танцювала теща, співали:

Ой, чоботи, чоботи ви мої,

Наробили клопоту ви міні!

Чоботи, чоботи ви мої,

Наробили клопоту ви міні!

Оце ції чоботи, що зять дав,

А за ції чоботи дочку взяв.

Чоботи, чоботи ви мої,

Наробили клопоту ви міні!
Ой це ж тії чоботи, що з бичка, Чом же ви не робите, як дочка? Чоботи, чоботи ви мої, Наробили клопоту ви міні! На річку йшла - чоботи скрипіли А з річки йшла - чоботи хляпали. Чоботи, чоботи ви мої, Наробили клопоту ви міні!

Під аналогічну пісню танцював і батько, вихваляючи свій подарунок: «Оце тії рукавиці, що зять дав!» (Кримський, 2009, с. 129).

Наведений опис, що документує побутування обрядового танцю-гри станом на 20-ті роки минулого століття, не дає повного уявлення про карнавальну атмосферу, в якій він відбувався. Цікаві подробиці щодо цього містять польові етнографічні матеріали останніх десятиліть.

За традицією, перш ніж одягнути на тещу нові чоботи, зять має помити їй ноги. Витоки цього звичаю треба шукати в середньовічному християнстві, якому відомий благочестивий обряд миття ніг прочанам і жебракам, здійснюваний представниками церковного кліру. В умовах «перевернутого сміхового буття» весільної перезви звичайна гігієнічна процедура набуває яскраво пародійного звучання. Замість того, щоб обмити ноги тещі чистою водою з милом, зять, під загальний регіт і жарти, обляпує їх грязюкою або сажею, масажує за допомогою кропиви, використовує для удаваного педикюру дротяну щітку, терпуг або звичайну цеглину. Щоб посилити комічний ефект обряду, тещу іноді змушують попередньо танцювати у валянках або старих (часто розпарованих) шкарбанах під відому нам пісню. Лише після цього акту осміяння, згідно з карнавальним каноном, переходили до акту величання, коли зять шанобливо мив ноги тещі й витирав їх чистим рушником. Останнім часом, щоб підкреслити урочисто-сміховий характер церемонії, замість води можуть використовувати одеколон, горілку чи шампанське. Обрядове дійство відбувається публічно і неодмінно супроводжується веселими коментарями й жартами весільних гостей. Взуваючи тещу в нові чоботи, зять жартівливо співає:

$$
\begin{aligned}
& \text { Тещу у чоботи узуваю, } \\
& \text { Узуваю, мамою називаю, } \\
& \text { Я буду зятем хорошим, } \\
& \text { щоб давала теща гроші... }
\end{aligned}
$$

(Курочкін, 2007b).

Згадка про гроші в наведеній пісні не випадкова. Вона відображає загальний тренд сучасної весільної звичаєвості до акцентування меркантильних стосунків 
між людьми. Показовий у цьому сенсі етнографічний опис із Житомирщини: «Як одягають нові чоботи, - повідомляє респондентка, - то не можуть взути. Теща каже, що тісні. Тоді зять стеле гроші в чоботи. Ще раз приміряють - тісні. Знову зять кладе гроші. Теща може й п’ять разів бути невдоволеною. Як побачить, що вже багато поклав, каже “добре” (бо де ж він бідний, буде гроші брать). Потім зять із тещею танцюють на столі. Якщо стіл високий, то вилазять на нього по драбині. Тут співають сороміцькі пісні» (Курочкін, 2007а).

Важливо наголосити, що в традиційному світогляді слов'ян та інших європейських народів хатній стіл і лави відігравали важливу символічну роль, вони співвідносилися з ідеєю святості. Екстатичні стрибки-танці тещі й зятя на столі - явне відхилення від правила й святотатство з позицій християнської моралі. Вірогідно, що тут маємо справу з пережитками ще язичницького світогляду, у рамках якого ритуальні танці з явними елементами деструкції мали виконувати магічну функцію продовження роду.

Пародійний танець зятя із тещею у багатьох місцевостях України - стабільна компонента весільного дійства, хоча окремі деталі цього обряду істотно відрізняються. Подекуди замість чобіт тещі можуть подарувати тепер модні туфлі, а для жарту - калоші або ласти. Варіативну природу мають тексти пісні, яка супроводжує танець «Чоботи». До канонічної основи нерідко додаються нові куплети й мотиви, що характеризують переживання матері у зв'язку з переходом дочки в іншу сім'ю. У багатьох локальних варіантах фіксується тенденція до вкраплення в пісню «Чоботи» елементів обсценної лексики, що аж ніяк не шокує учасників весільної перезви.

Як правило, зять і теща виконують танець під гармошку й бубон або під так звану «саморобну музику» (див. вище). Відомо, що в давні часи на весіллях могли грати й лірники. У їхньому репертуарі були такі танці як «Гопачок», «Козачок», «Чоботи». Відтворюючи ці мелодії, лірники час від часу вигукували окремі слова, що називалося «грати з приказом».

Спільний танець зятя й тещі, як обов'язковий компонент ритуалу, разом із розважально-ігровою виконував важливу морально-етичну функцію, символізуючи єднання і взаємоповагу членів нової родини. На Яготинщині записано прислів’я: «Хто тещу в чоботи взуває, той любов, підтримку й гроші від неї має».

Враховуючи характерні стилістичні особливості народної хореографії, А. Гуменюк (1963) свого часу спробував визначити три основні жанри, характерні для неї: обрядові, побутові та сюжетні (с. 51). Ця класифікація не релевантна стосовно конкретних танців-ігор, оскільки вони містять у собі ознаки всіх трьох названих жанрів. Це ще одна грань синкретизму традицій народної творчості.

Наукова новизна. У статті здійснено першу спробу визначити ролі, функції та семантику обрядових танців-ігор як невід’ємної частини традиційного весільного ритуалу українців.

Висновки. Систематизовані фольклорно-етнографічні матеріали дають змогу скласти певне уявлення про такий самобутній феномен традиційної культури українців, як весільні танці-ігри. Під впливом клерикальної, моральної та ідеологічної цензури, а також через соромливо-пуританське ставлення до еротичного пласту ритуалістики самих науковців вони тривалий час залишалися поза увагою дослідників. 
Є всі підстави вважати, що охарактеризовані нами танці-ігри в попередні часи виконували магічну функцію, яка полягала в чаклуванні щасливого шлюбу, продовження роду та зміцнення сімейних зв'язків. Віра в досягнення цих цілей через випробований предками обрядовий механізм обумовлювала стійкість традицій. У процесі історичної еволюції давні магічні практики втрачали зв'язок із сакральною сферою, поступово трансформуючись у традиційні розважальноігрові звичаї й церемонії.

Розглянуті обрядові комплекси «Журавель», «Зайчик», «Танці на рядні», «Чоботи» яскраво ілюструють синкретичний характер народного мистецтва, зв'язок танців із грою, піснею, музикою, драматичною видовищністю. До коктейлю весільних розваг перезвянського циклу обов'язково входили також гумор, сміх, веселі бешкети і карнавальна свобода - типові прикмети національної вдачі українців.

Наша розвідка - це лише перша спроба етнокультурної характеристики весільних обрядових танців-ігор. Надалі потрібний аналіз фахових етнохореологів, які, володіючи сучасною методикою запису танцю, зможуть простежити всі нюанси пластики і ритмічний малюнок рухів виконавців.

Традиційна весільна обрядовість українців зазнає скорочення, збіднення та модифікації під впливом міста й масової культури. Проте й сьогодні в деяких місцевостях проаналізовані розважально-ігрові комплекси відтворюються в автентичному вигляді. Отже, передчасно вести мову про відсутність джерельної бази для подальшого вивчення реального стану функціонування народної звичаєвості. Проведене дослідження цілком підтвердило тезу про генетичну й семантичну спорідненість традиційних весільних ігор і танців з весільними піснями, що засвідчує доцільність їх подальшого вивчення в синхронічній взаємообумовленості.

\section{СПИСОК БІБЛІОГРАФІЧНИХ ПОСИЛАНЬ}

Бантыш-Каменский, Д.Н. (1993). История Малой России. Киев: Час.

Вовк, Х. (1995). Студії з української етнографії та антропології. Київ: Мистецтво.

Волошин, I.O. (1960). Джерела народного театру на Україні. Київ: Державне видавництво образотворчого мистецтва і музичної літератури УРСР.

Гнатюк, В. (Ред.). (1919). Матеріали до української етнології (Т. 19-20). Львів: НТШ.

Гриша, О. (1899). Весілля у Гадяцькому повіті у Полтавщині. В Х. Вовк (Ред.), Матеріали до українсько-руської етнологї (Т. 1, с. 111-156). Львів: НТШ.

Грушевський, М. (1993). Історія української літератури (Т. 1). Київ: Либідь.

Гуменюк, А. (1963). Народне хореографічне мистецтво України. Київ: Видавництво АН УРСР.

Гура, А.В. (1978). Символика зайца в славянском обрядовом и песенном фольклоре. В И.М. Шептунов (Ред.), Славянский и балканский фольклор. Генезис. Архаика. Традиции (с. 159-189). Москва: Наука.

Гура, А.В. (1997). Символика животных в славянской народной традиции. Москва: Индрик.

Журавель. (1971). В І.В. Білодід \& Л.А. Юрчук (Ред.), Словник української мови (Т. 2, с. 547). Київ: Наукова думка.

Котляревський, І. (1982). Поетичні твори. Драматичні твори. Листи. Київ: Наукова думка.

Кримський, А. (2009). Звенигородщина. Шевченкова батьківщина з погляду етнографічного та діалектологічного. Черкаси: Вертикаль. 
Курочкін, О.С. (1982). Високі Байраки, Кіровоградського району та області: польові матеріали автора. Особистий архів О.С. Курочкіна, Київ.

Курочкін, О.С. (1988). Польові матеріали автора. Особистий архів О.С. Курочкіна, Київ.

Курочкін, О.С. (1990). Польові матеріали автора. Особистий архів О.С. Курочкіна, Київ.

Курочкін, О.С. (1991). Скельки Васильківського району Дніпропетровської області: польові матеріали автора. Особистий архів О.С. Курочкіна, Київ.

Курочкін, О.С. (2002). Архаїчний весільний танець-гра «Журавель» («Бусел»). Наукові записки НаУКМА. Історія і теорія культури, 20-21, 25-34.

Курочкін, О.С. (2004а). Еротичні весільні ігри українців. Берегиня, 1, 27-38.

Курочкін, О.С. (2004b). Українці в сім’ї європейській: звичаї, обряди, свята. Київ: Бібліотека українця.

Курочкін, О.С. (2007а). Ставники, Радомишльського району Житомирської області: польові матеріали автора. Особистий архів О.С. Курочкіна, Київ.

Курочкін, О.С. (2007b). Теремне Рівненського району і області: польові матеріали автора. Особистий архів О.С. Курочкіна, Київ.

Курочкін, О.С. (2009). Весільне рядження - «циганщина». Берегиня, 1, 5-18.

Курочкін, О.С. (2011). Польові матеріали автора. Особистий архів О.С. Курочкіна, Київ.

Курочкін, О.С. (2015). Традиційне весілля у контексті розважально-сміхової культури українців. Університет, 2-6, 78-92.

Курочкін, О.С. (2016). Народний обряд «старече весілля». Народна творчість та етнологія, 2, 66-67.

Курочкін, О.С. (2017). Архаїчні слов’янські танці - «скоки». Сіверянський літопис, 1-2, 262269.

Маркевич, Н. (Сост.). (1991). Обычаи, поверья, кухня и напитки малороссиян. Київ.

Олянчин, Д. (1937). Опис подорожі шведського посла на Україну 1656-1657 р. В Записки НТШ (Т. 154). Львів.

Прохорчук, О. (1996). Танцювальний фольклор Рівненського Полісся. В Проблеми успадкування зимових народних звичаїв та обрядів, Матеріали і тези Другої науково-практичної конференції (с. 66). Рівне.

Ящуржинский, Х. (1896). Свадьба малорусская как религиозно-бытовая драма. Киев: Типография Корчак-Новицкого.

Moszynski, K. (1968). Kultura ludowa slowian. Kultura duchowa (T. 2, Cz. 2). Warszawa.

\section{REFERENCES}

Bantysh-Kamenskii, D.N. (1993). Istoriya Maloнy Rossii [History of Little Russia]. Kyiv: Chas [in Russian].

Gura, A.V. (1978). Simvolika zaitsa v slavyanskom obryadovom i pesennom folklore [Symbolism of a hare in Slavic ritual and song folklore]. In I.M. Sheptunov (Ed.), Slavianskii i balkanskii folklor. Genezis. Arkhaika. Traditcii [Slavic and Balkan folklore. Genesis. Archaic. Traditions] (pp. 159-189). Moscow: Nauka [in Russian].

Gura, A.V. (1997). Simvolika zhivotnykh v slavyanskoy narodnoy traditcii [Symbolism of animals in the Slavic folk tradition]. Moscow: Indrik [in Russian].

Hnatiuk, V. (Ed.). (1919). Materialy do ukrainskoi etnolohii [Materials on Ukrainian Ethnology] (T. 19-20). Lviv: NTSh [in Ukrainian].

Hrushevskyi, M. (1993). Istoriia ukrainskoi literatury [History of Ukrainian Literature] (Vol. 1). Kyiv: Lybid [in Ukrainian]. 
Hrysha, O. (1899). Vesillia u Hadiatskomu poviti u Poltavshchyni [Wedding in Hadyatsky county in Poltava region]. In Kh. Vovk (Ed.), Materialy do ukrainsko-ruskoi etnolohii [Materials on Ukrainian-Russian ethnology] (Vol. 1, pp. 111-156). Lviv: NTSh [in Ukrainian].

Humeniuk, A. (1963). Narodne khoreohrafichne mystetstvo Ukrainy [Folk choreographic art of Ukraine]. Kyiv: Vydavnytstvo AN URSR [in Ukrainian].

Iashchurzhinskii, Kh. (1896). Svadba malorusskaya kak religiozno-bytovaya drama [Little Russian wedding as a religious drama]. Kyiv: Tipografiia Korchak-Novitckogo [in Russian].

Kotliarevskyi, I. (1982). Poetychni tvory. Dramatychni tvory. Lysty [Poetry. Dramatic works. Letters]. Kyiv: Naukova dumka [in Ukrainian].

Krymskyi, A. (2009). Zvenyhorodshchyna. Shevchenkova batkivshchyna z pohliadu etnohrafichnoho ta dialektolohichnoho [Zvenigorod Region. Shevchenko's homeland from the point of view of ethnographic and dialectological]. Cherkasy: Vertykal [in Ukrainian].

Kurochkin, O.S. (1982). Vysoki Bairaky, Kirovohradskoho raionu ta oblasti: polovi materialy avtora [Vysoki Bairaky, Kirovohrad district and region: author's field materials]. Kurochkin's personal archive, Kyiv [in Ukrainian].

Kurochkin, O.S. (1988). Polovi materialy avtora [Author's field materials]. Kurochkin's personal archive, Kyiv [in Ukrainian].

Kurochkin, O.S. (1990). Polovi materialy avtora [Author's field materials]. Kurochkin's personal archive, Kyiv [in Ukrainian].

Kurochkin, O.S. (1991). Skelky Vasylkivskoho raionu Dnipropetrovskoi oblasti: polovi materialy avtora [Skelky of Vasylkiv district of Dnipropetrovsk region: author's field materials]. Kurochkin's personal archive, Kyiv [in Ukrainian].

Kurochkin, O.S. (2002). Arkhaichnyi vesilnyi tanets-hra "Zhuravel" ("Busel") [Archaic wedding dance game "Zhuravel" ("Busel")]. NaUKMA Research Papers. History and theory of culture, 20-21, 25-34 [in Ukrainian].

Kurochkin, O.S. (2004a). Erotychni vesilni ihry ukraintsiv [Erotic wedding games of Ukrainians]. Berehynia, 1, 27-38 [in Ukrainian].

Kurochkin, O.S. (2004b). Ukraintsi v simi yevropeiskii: zvychai, obriady, sviata [Ukrainians in the European family: customs, rituals, holidays]. Kyiv: Biblioteka ukraintsia [in Ukrainian].

Kurochkin, O.S. (2007a). Stavnyky, Radomyshlskoho raionu Zhytomyrskoi oblasti: polovi materialy avtora [Stavnyky, Radomyshl district, Zhytomyr region: author's field materials]. Kurochkin's personal archive, Kyiv [in Ukrainian].

Kurochkin, O.S. (2007b). Teremne Rivnenskoho raionu i oblasti: polovi materialy avtora [Teremne of Rivne district and region: author's field materials]. Kurochkin's personal archive, Kyiv [in Ukrainian].

Kurochkin, O.S. (2009). Vesilne riadzhennia - "tsyhanshchyna" [Wedding dresses - "gypsy"]. Berehynia, 1, 5-18 [in Ukrainian].

Kurochkin, O.S. (2011). Polovi materialy avtora [Author's field materials]. Kurochkin's personal archive, Kyiv [in Ukrainian].

Kurochkin, O.S. (2015). Tradytsiine vesillia u konteksti rozvazhalno-smikhovoi kultury ukraintsiv [Traditional wedding in the context of entertainment and funny culture of Ukrainians]. Universytet, 2-6, 78-92 [in Ukrainian].

Kurochkin, O.S. (2016). Narodnyi obriad "stareche vesillia" [Folk rite "Older wedding"]. Narodna tvorchist ta etnolohiia, 2, 66-67 [in Ukrainian].

Kurochkin, O.S. (2017). Arkhaichni slovianski tantsi - "skoky" [Archaic Slavic dances are "skoky"]. Siverianskyi litopys, 1-2, 262-269 [in Ukrainian].

Markevich, N. (Comp.). (1991). Obychai, poveriya, kukhnya i napitki malorossiyan [Customs, beliefs, cuisine and drinks of Little Russians]. Kyiv [in Russian].

Moszynski, K. (1968). Kultura ludowa slowian. Kultura duchowa [Slavic folk culture. Spiritual culture] (Vol. 2, Pt. 2). Warszaw [in Polish]. 
Olianchyn, D. (1937). Opys podorozhi shvedskoho posla na Ukrainu 1656-1657 r [Description of the Swedish Ambassador's voyage to Ukraine in 1656-1657]. In Zapysky NTSh [Notes by NTSH] (Vol. 154). Lviv [in Ukrainian].

Prokhorchuk, O. (1996). Tantsiuvalnyi folklor Rivnenskoho Polissia [Dance folklore of Rivne Polesie]. In Problemy uspadkuvannia zymovykh narodnykh zvychaiv ta obriadiv [Problems of inheritance of winter folk customs and rituals], Proceedings and abstracts of the $2^{\text {nd }}$ Scientific and Practical Conference (p. 66). Rivne [in Ukrainian].

Voloshyn, I.O. (1960). Dzherela narodnoho teatru na Ukraini [National Theater Sources in Ukraine]. Kyiv: Derzhavne vydavnytstvo obrazotvorchoho mystetstva i muzychnoi literatury URSR [in Ukrainian].

Vovk, Kh. (1995). Studii z ukrainskoi etnohrafii ta antropolohii [Studies in Ukrainian ethnography and anthropology]. Kyiv: Mystetstvo [in Ukrainian].

Zhuravel [Crane]. (1971). In I.V. Bilodid \& L.A. Yurchuk (Ed.), Slovnyk ukrainskoi movy [Dictionary of Ukrainian] (Vol. 2, p. 547). Kyiv: Naukova dumka [in Ukrainian]. 